\title{
Total rewards strategy for a multi-generational workforce in a financial institution
}

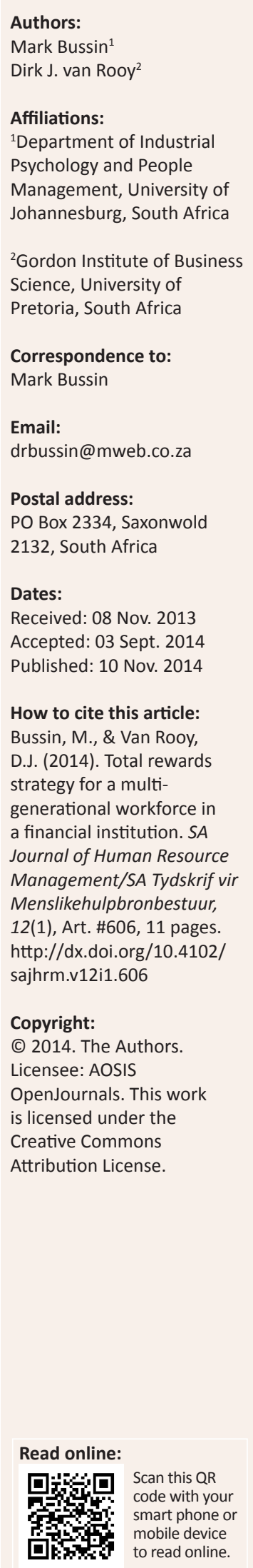

Orientation: Different generations may value and perceive employee rewards differently. This impacts on reward strategies in the workplace which have been specifically developed to attract, retain and motivate staff. A one-size-fits-all approach to reward strategy may not achieve the objectives intended, leading to direct and indirect financial implications for businesses.

Research purpose: This study investigated whether perceptions of reward strategy differed across generations in a large financial institution in South Africa. This context was specifically chosen due to the significant competition to attract and retain staff that exists in the financial sector. To contribute to the practical challenges of reward implementation, the study investigated whether specific reward preferences associated with generation exist, and whether offering rewards based on these preferences would successfully attract and retain staff.

Motivation for study: South African businesses are competing for skilled staff and rely heavily on a total reward strategy to compensate all generations of employees. Given the financial incentives to retain and attract the most effective staff, it is essential that reward strategies meet their objectives. All factors impacting the efficacy of reward strategies should be considered, including the impact of generational differences in preference. This is of relevance not only to the financial industry, but to all companies that employ staff across a variety of generations.

Research design, approach and method: A quantitative survey design was used. A total of 6316 employees from a financial firm completed a survey investigating their experiences and perceptions of reward strategies. Statistically significant differences across different generations and reward preferences were considered.

Main findings: Significant differences in reward preferences were found across generational cohorts. This supports international literature.

Practical/managerial implications: The results indicate that there is an opportunity for businesses and managers to link components of the total reward strategy to specific generations in the workforce by offering a wider variety of reward options to employees. Employee perceptions indicate a willingness to have reward strategies tailored to their needs and to have a greater say in their reward strategies. The challenge is in presenting the options in a fair and transparent manner, in providing choice and in tracking long-term retention and motivation based on the reward strategy.

Contribution: The study found that generations value rewards differently, which will enable management to develop more strategic approaches to reward. This research extends international evidence to include workplaces in emerging economies, which have the additional challenges of high rates of unemployment, but also scarce skills and competition for skilled staff. The findings of this research go some way to support the need to develop more dynamic, flexible and generation-specific reward strategies to support staff retention and attraction.

\section{Introduction}

\section{Problem statement}

\section{Key focus}

In the South African workplace, organisations are not merely competing against traditional competitors in the war for talent, but also against other high-skill workplaces, a labour market with very low numbers of high-skill and medium-skill people, high levels of mobility amongst the workforce and fewer skills entering the workforce (Bussin \& Moore, 2012). The most explicit means to attract and retain staff, the reward strategy, has traditionally been thought of as linear: the greater the reward offered, the more likely the workplace is to attract the individual. This does not, however, take into account the complexity of the nature of the reward or the 
individual. Rewards can be multifaceted and both financial and non-financial. Many features of reward strategies have not been incorporated into a total reward strategy (Hayes, 1999; Irvine, 2010). In addition, individuals have different sets of values and motivations. One influencing factor that has received prominence in international literature is the effect of the values of different generations in terms of what motivates them from a reward perspective. The argument is that employees from different generations have different needs and perceptions of what constitutes value in reward. The question is whether this trend is evident in an emerging economy, where there are high levels of skills shortages but also high levels of unemployment.

\section{Background}

The South African financial sector's workforce is 91\% skilled and highly skilled; half are under the age of 35 years and $9 \%$ above age 50 . The sector faces a decline in workforce at the lower skills levels and high competition for skilled employees (BankSETA, 2010). A survey by Landelahni (2010) Financial Services found that the challenges in attracting and retaining staff for the financial sector include a slow recovery for the sector, a shortage of key staff locally and globally and greater mobility of staff. These problems will not be solved in the short term and strategies are needed to increase skills and training and to better manage talent.

Sector skills plans and human resource plans tend to focus on developing skills in school leavers and in existing staff. Scant attention has been paid to other human resource strategies such as reward strategies in creating an attractive work environment. This research contributes to the literature on retaining and attracting skilled staff by using human resource strategies already in place, but finding ways to improve their efficacy.

South Africa is an emerging economy facing the international development challenges of, amongst others, high unemployment and a vast skills deficit (BankSETA, 2010; Horwitz, Bowmaker-Falconer \& Searll, 1996). The challenge for business in this environment is to attract and retain capable, high-quality employees.

\section{Research purpose}

International research advocates for reward strategies that are tailored to specific generational cohorts. This research set out to determine whether this trend is applicable and relevant in South Africa, where there are high levels of skills shortages but also high levels of unemployment. To assess the relevance of using generational preferences in reward strategy to attract and retain staff, the research also investigated whether generational preferences towards reward exist in the financial sector in South Africa.

\section{Trends from research literature}

The idea that values and preferences in the workplace differ across generations has been presented for over a decade (Codrington, 2008; Deal, Stawiski, Graves, Gentry \& Ruderman, 2013; Lyons, 2003), as has the view that workplaces should develop relevant reward and retention strategies to suit multiple needs. Reward systems that assist employees to determine and achieve their immediate career objectives are not straightforward (Armstrong \& Murlis, 2007; Cummings \& Worley, 2001). Bonuses and commissions may have a transient motivational effect that results solely in temporary adjustments and does not result in lasting commitment (Khon, 2002; Scott \& McMullen, 2010). Recent research from the South African context has found that specific compensation strategies directly impact the retention of Generation Xers, along with work content, career advancement, work-life balance, security needs, leadership and drive (Masibigiri \& Nienaber, 2011). However, Bussin and Moore (2012) found no reward preferences amongst generational groups in a sample of 164 employees from two information and communication technology (ICT) organisations.

\section{Objectives}

Based on the above research trends, the current study was undertaken to answer the following research questions:

- Does a generation-based preference for reward exist?

- Does a total reward strategy address the preferences of each of the individual generations?

- Do generation-specific rewards improve the company's ability to attract, motivate and retain their employees?

\section{Contribution to field}

This research contributes to the international literature on generation reward preferences and extends the evidence to include workplaces in emerging economies with the pressure of high unemployment and scarce skills. The findings have direct relevance to the workplace and contribute specific insight into generational preferences in rewards. The workplace will benefit from the findings of this research by using the results to support the definition and customisation of reward packages based on generational theory.

\section{Literature review}

\section{Differences in generational values and preferences}

The workplace has changed significantly in the last decade, and the financial sector even more so. The sector is faced with sluggish growth after the great financial crisis of 2008, a slowdown in most economies, increases in technology, greater risk and compliance requirements, higher threats from money laundering and fraud and higher demands on productivity. In order to deal with these changes, the sector relies on the skills of its workforce. This talent management is essential for competitive advantage (Bersin, 2008; Ellis, 2009; Linne, 2009; Mohlala, 2011). Successful talent management includes being relevant to the needs of the workforce and taking into account the diverse needs of different generation groups.

Although past research (e.g. Masibigiri \& Nienaber, 2011) has focused on the needs of different generations, the challenge of accurately defining generational cohorts remains. Definitions tend to be inconsistent (Lancaster \& Stillman, 2002; Shaul, 2007). Smola and Sutton (2002) take the view that historical and social events shape the lives of specific general cohorts and can 
TABLE 1: Summary of workplace generation characteristics.

\begin{tabular}{|c|c|}
\hline Generation & Characteristics \\
\hline $\begin{array}{l}\text { Veterans, } \\
\text { traditionalists, } \\
\text { Silent Generation }\end{array}$ & $\begin{array}{l}\text { Lived through the Great Depression and War } \\
\text { Are loyal } \\
\text { Focus on lifestyle in remuneration considerations } \\
\text { The job is the reward }\end{array}$ \\
\hline Baby Boomers & $\begin{array}{l}\text { Born after Second World War: Shift to more global environments } \\
\text { High levels of competition } \\
\text { Loyal and hardworking } \\
\text { Looking to extend their work life in difficult economic climate } \\
\text { Need public recognition }\end{array}$ \\
\hline Generation X & $\begin{array}{l}\text { Early to middle part of their career } \\
\text { Often challenge the status quo } \\
\text { Exposed to explosion of new media } \\
\text { Independent and may be destructive to group work } \\
\text { Freedom in the form of a work-life balance }\end{array}$ \\
\hline Generation Y & $\begin{array}{l}\text { Present many challenges to managers } \\
\text { Use multiple information channels and have a constant need for } \\
\text { knowledge which they find empowering } \\
\text { But are realistic in the challenges they must overcome } \\
\text { Practical rewards and want rewards now }\end{array}$ \\
\hline
\end{tabular}

Source: Compiled from Bussin and Fletcher (2008); Colon (2005); Lancaster and Stillman (2002); Orciani (2009); Zemke, Raines and Filipczack (2000)

Note: Please see the full reference list of the article, Bussin, M., \& Van Rooy, D.J. (2014). Total rewards strategy for a multi-generational workforce in a financial institution. SA Journal of rewards strategy for a multi-generational workforce in a financial institution. SA Journal of
Human Resource Management/SA Tydskrif vir Menslikehulpbronbestuur, 12(1), Art. \#606, 11 Human Resource Management/SA Tydskrif vir Menslikehulpbronbestuur,
pages. http://dx.doi.org/10.4102/sajhrm.v12i1.606, for more information.

be used to define them. These events undoubtedly differ across countries (Codrington, 2008; Codrington \& Grant-Marshall, 2004) and generational definitions may lose relevance when extrapolated widely across different countries. Codrington (2008), however, argues that specific age groups are likely to have similar value systems regardless of their environment. These value systems drive and motivate behaviour, making them an important area of study in work motivation and preference. The most common generational categories linked to age are the following (Lancaster \& Stillman, 2002):

- Veterans (traditionalists) - (Born 1900-1945)

- Baby Boomers (or Boomers) - (Born 1946-1964)

- Generation X - (Born 1965-1980)

- Generation Y - (Born 1981-1999).

The challenge is that despite the fact that these categories may not apply to the South African context, they have become part of human resources literature terminology. The definitions of Lancaster and Stillman (2002) tend to be the least event-defined and are broad in scope. Table 1 lists the characteristics of each cohort in the workforce.

Table 1 outlines the views and workplace values from the generational cohorts as outlined by Lancaster and Stillman (2002). Other researchers, such as Kane (2013), use the first three categories in the workplace as veterans are not widely represented. A similar under-representation of veterans was also found in the current study.
Generations differ in personal values, work methods and ethics and communication and socialisation outside of work (Kupperschmidt, 2000). Orciani (2009) argues that great leaders are able to take advantage of the strengths of each generation.

The differences between generations can also lead to conflict. For instance, veterans and younger groups often differ in the value placed on loyalty to an organisation (Colon, 2005; Hatfield, 2002; Zemke, Raines \& Filipczack, 2000), the competitiveness of Boomers may be perceived as aggressive by other groups (Orciani, 2009) and Generation Xers value feedback to an extent not understood by older generations (Glass, 2007; Orciani, 2009; Smola \& Sutton, 2002). According to Irvine (2010), the majority of the workforce is now made up of Boomers (45\%), followed by Generation Xers (30\%).

As Boomers exit the workforce, managers need to be able to adapt to the needs and values of Generation Xers, and Generation Ys. This generational mix requires managers to adapt and reinvent their retention and compensation programmes to take different values, needs and work ethics into account (Milgram, 2008).

\section{Total reward programmes}

Reward is considered a significant tool to attract, motivate and retain employees (Boyd \& Salamin, 2001). "Total reward' programmes, however, include both monetary and non-monetary rewards (E-research, 2002). Monetary rewards include basic pay, variable pay, share ownership and employee benefits. Non-monetary rewards are almost anything else an organisation offers an employee. Shaul (2007) has noted that employees focus on monetary reward but, paradoxically, their behaviour is often driven by nonmonetary rewards. These non-monetary rewards are part of the psychological contract between employee and employer.

WorldatWork's (2006) model of total reward includes five elements (Table 2 and Figure 1):

- compensation

- benefits

- work-life

- performance and recognition

- development and career opportunities.

The above five elements are illustrated in Figure 1, demonstrating how the total reward elements and the company as a whole combine and influence each other.

\section{Research design \\ Research approach}

A quantitative, survey research design was chosen in order to reach a large portion of participants in a financial institution

TABLE 2: Five elements and examples of the model for total reward strategy.

\begin{tabular}{ll}
\hline Compensation & Salaries and incentives \\
\hline Benefits & Retirement and health care \\
Work-life & Workplace flexibility and paid and unpaid leave \\
Performance recognition & Performance planned by performance reviews; recognition in the form of annual awards, et cetera \\
Development and career opportunities & Learning opportunities and mentoring \\
\hline
\end{tabular}

Source: WorldatWork. (2006). WorldatWork total rewards model. Retrieved November 15, 2013, from http://www.worldatwork.org/waw/aboutus/html/aboutus-whatis.html 
within a set amount of time provided by the institution. The design was cross-sectional to include a 'snapshot' of all generational cohorts at one point in time.

The independent variable is generations as defined in 'differences in generational values and preferences'. The dependent variables include employees' perceptions and preferences for total reward strategies.

\section{Research method}

\section{Research participants}

The participants in this study were from a large financial services company in South Africa. Participants were identified through convenience non-probability sampling. The organisation has approximately 29000 employees across South Africa. A definitive total number was not available. All employees in South Africa (all provinces were included) with Internet access were asked to complete a survey via an email with a link to the online survey. This method was used to reach the greatest number of people, across the largest number of locations. The deadline was 2 weeks. The questionnaire was completed by 6316 people, resulting in a $24 \%$ response rate overall.

The participants in this study fell predominantly in the Generation X classification, which reflects the characteristics of the sector in South Africa (BankSETA, 2010). The participants were $60 \%$ Generation X, 28\% Generation Y, 12\% Boomers and only $0.05 \%$ veterans (this supports Kane's, 2013, view that the majority of the workplace is made up of the first three groups).

Table 3 outlines the demographic characteristics of the respondents. The demographic characteristics were determined from the personnel numbers attached to the completed surveys. The limitation of this method was that characteristics such as marital status and specific geographic location were not available.

No veterans responded to the survey. It is unclear why this was the case. The other generation groups were comparable to the population composition of the organisation.

\section{Measuring instruments}

The survey instrument was Internet based and was communicated to employees via email. It was part of a

TABLE 3: Demographic characteristics of the respondents.

\begin{tabular}{llll}
\hline Characteristics & Distribution & $\begin{array}{l}\text { Number of } \\
\text { participants }\end{array}$ & Percentage \\
\hline Generation & Baby Boomer & 1161 & 18.38 \\
& Generation X & 3210 & 50.82 \\
& Generation Y & 1945 & 30.80 \\
Tonder & Total & 6316 & 100.00 \\
& Male & 2159 & 34.18 \\
Racial & Female & 4157 & 65.82 \\
& Total & 6316 & 100.00 \\
& African & 1876 & 29.70 \\
& Mixed race & 1146 & 18.14 \\
Years with employer & White & 2392 & 37.87 \\
& Indian & 900 & 14.26 \\
& Foreign nationality & 2 & 0.03 \\
& Total & 6316 & 100.00 \\
& $6-10$ & 295 & 4.67 \\
& $11-15$ & 2956 & 46.80 \\
& $16-20$ & 1087 & 17.21 \\
& $>20$ & 790 & 12.51 \\
& Total & 356 & 5.64 \\
& & 832 & 13.17 \\
& 6316 & 100.00 \\
\hline
\end{tabular}

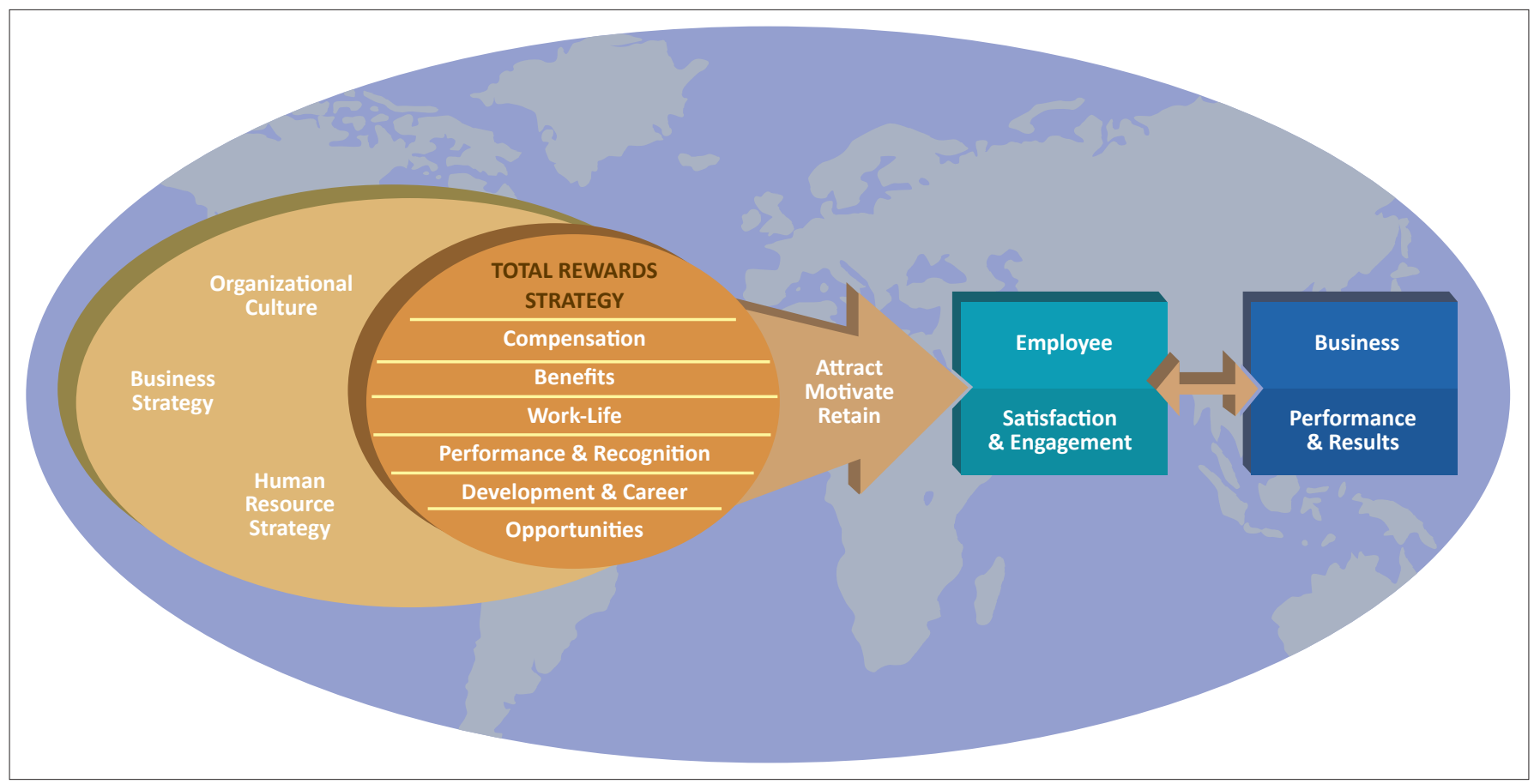

Source: WorldatWork. (2006). WorldatWork total rewards model. Retrieved November 15, 2013, from http://www.worldatwork.org/waw/aboutus/html/aboutus-whatis.html FIGURE 1: WorldatWork (2006) total reward strategy model. 
larger, company-based survey, thus enabling the use of the workplace process of research. The survey used closed-ended questions, with ratings on a five-point Likert-type scale from 1 (extreme negative) to 5 (extreme positive).

The survey was designed based on the components from the WorldatWork total reward strategy model (WorldatWork, 2008). Demographic information was determined using the employees' personnel numbers which they supplied and were linked to their responses. Employees were informed of the intention of the research and the need for the inclusion of their personnel numbers. This information was kept confidential, accessed only by the researcher and maintained in a protected database.

The survey was piloted on a small group of employees to determine the time taken to complete the survey and to identify any ambiguities or difficulties with the survey. These pilot participants were excluded from the final sample. A Cronbach's alpha score of reliability of 0.82 was obtained for the questions, above the acceptable level of 0.70 (DeVills, 2003; Pallant, 2007).

\section{Research procedure}

Before administration, the survey was piloted on a small group of employees located in the call centre of the organisation. The survey was finalised using the findings from the pilot group and then sent to all employees in South Africa via email. The survey was completed online and the researcher was able to access the final results online. A notice letter reminding the employees of the closing date was sent 1 week after the survey was initially sent out to encourage participation. Participation in the research survey was voluntary and no pressure was placed on respondents to participate. Once the responses were received, analysis of data using a variety of statistical analysis techniques was performed.

\section{Statistical analysis}

The responses from the questionnaire were uploaded to an Internet-based survey tool and then exported to an Excel spreadsheet. Descriptive statistics, frequencies and bivariate cross-tabulations were conducted. Inferential statistics included Spearman's correlations, the Kruskal-Wallis test and Bonferoni correction.

\section{Ethical considerations}

Permission to conduct the research was granted by the organisation. Participation in the research was voluntary and employees were also explicitly asked for their consent before completing the survey. Respondents' employee numbers were linked to the survey, thus anonymity was not possible. However, the data was kept confidential and only seen by the researcher and supervisor (who performed the statistical analysis). Data will be destroyed after 2 years.

\section{Results}

The following section discusses the statistical analysis performed to answer each research question.

\section{Research question 1: Does a generation-based preference for reward exist?}

Participants were asked to list the rewards they had received in the last 18 months. Table 4 outlines the types of rewards and generational preference for them. Spearman's

TABLE 4: The total reward package that was received by employees.

\begin{tabular}{|c|c|c|c|}
\hline Reward type & Spearman correlation co-efficient & $\begin{array}{l}\text { Difference in medians (Kruskal-Wallis } \\
\text { analysis of variance) }\end{array}$ & $\begin{array}{l}\text { Difference between groups } \\
\text { (Bonferroni test) }\end{array}$ \\
\hline Long service awards & $P=-0.214^{* *}$ & $p<0.01$ & All groups differ from each other \\
\hline $\begin{array}{l}\text { Time off work in recognition of hard work } \\
\text { and secondment }\end{array}$ & $P=0.085^{* *}$ & $p<0.01$ & All groups differ from each other \\
\hline Mentorship and coaching programme & $P=0.068^{* *}$ & $p<0.01$ & All groups differ from each other \\
\hline Structured development programme & $P=0.077^{* *}$ & $p<0.01$ & All groups differ from each other \\
\hline Flexible working hours & $P=0.018^{* *}$ & $p<0.01$ & All groups differ from each other \\
\hline Salary & $P=-0.045^{* *}$ & $p<0.01$ & Groups 1 and 2 differ from Group 3 \\
\hline Annual leave commutation & $P=-0.048^{* *}$ & $p<0.01$ & Groups 1 and 2 differ from Group 3 \\
\hline Training courses & $P=-0.042^{* *}$ & $p<0.01$ & Groups 1 and 2 differ from Group 3 \\
\hline On-the-job training & $P=0.068^{* *}$ & $p<0.01$ & Groups 1 and 2 differ from Group 3 \\
\hline External conferences & $P=-0.045^{*} *$ & $p<0.01$ & Groups 1 and 2 differ from Group 3 \\
\hline Company share scheme & $P=-0.086 * *$ & $p<0.01$ & Groups 1 and 2 differ from Group 3 \\
\hline Company BEE share scheme & $P=-0.085^{* *}$ & $p<0.01$ & Groups 1 and 2 differ from Group 3 \\
\hline Pleasant work environment & $P=-0.055^{* *}$ & $p<0.01$ & Groups 1 and 2 differ from Group 3 \\
\hline $\begin{array}{l}\text { Outcome-based remuneration or } \\
\text { commission }\end{array}$ & $P=0.031^{*}$ & $p=0.016$ & Group 1 differs from Group 2 and 3 \\
\hline Study bursary - Fully paid & $P=0.053^{* *}$ & $p<0.01$ & Group 1 differs from Group 2 and 3 \\
\hline Gym facilities & $P=0.072^{* *}$ & $p<0.01$ & Group 1 differs from Group 2 and 3 \\
\hline Bonuses & $P=0.026$ & $p=0.090$ & Not applicable \\
\hline Cash Incentives & $P=0.013$ & $p=0.535$ & Not applicable \\
\hline Non-financial recognition awards & $P=0.024$ & $p=0.139$ & Not applicable \\
\hline Study bursary - Partially paid & $P=0.023$ & $p=0.050$ & Not applicable \\
\hline Wellness programme & $P=0.009$ & $p=0.148$ & Not applicable \\
\hline
\end{tabular}

Group 1, Generation Y; Group 2, Generation X; Group 3, Boomers.

${ }^{*}, p<0.5 ;{ }^{* *}=p<0.001$ 
correlations between the generational groups were run. A Kruskal-Wallis analysis of variance determined significant difference and a Bonferroni test indicated which groups differed from one another.

As can be seen from Table 4 all three generational cohorts differed on the following rewards they received: long service award, time off work in recognition of hard work and secondment, mentorship and coaching programmes, structured development programmes and flexible working hours. The younger Generation X and Generation Y groups differed from the Boomers on receiving rewards such as salary, annual leave commutation, training courses, onthe-job training, external conferences, the company share scheme, the company Black Economic Empowerment (BEE) scheme and pleasant working environment.

Overall, most participants received traditional rewards such as a salary and bonus. The older generation (Boomers) had a higher percentage of share ownership. The younger groups of Generation Xers and Generation Ys used resources such as gym facilities more, whilst older generations had a higher frequency of long service awards. These relatively predictable results are consistent with existing theory about generational preferences and indicate traditional rewards provided as seniority is achieved (Gentry, 2007; Nienaber, Bussin \& Henn, 2011).

Participants were then asked to choose the reward options they would prefer to receive. All groups differed significantly in their preferences. Table 5 outlines these preferences.

Table 5 highlights the fact that generational cohorts differ from each other on all the reward types. Table 6 highlights the preferences amongst respondents on a five-point scale from not important to very important. Frequencies were run to determine these preference types and a Bonferonni test was conducted to determine significance.

It is evident from Table 6 that each generation preferred different types of financial compensation. When compared to Boomers, Generation Y showed a preference for bonuses. The Generation $Y$ and Generation $X$ groups also preferred more 'health' and 'change the world' forms of benefits, evidenced in the higher gym and wellness uptake from these groups (Moore, 2009).

Generation Xers rated work-life balance very highly. They have a higher preference for 'flexible working hours' and a 'pleasant work environment' (Chan, 2005). In contrast, the Boomers preferred 'long service awards' which is consistent with their preference for public rewards (Bussin \& Fletcher, 2008).

With reference to development and career opportunities, Generation Ys appeared to be primarily focused on developing themselves and their careers (Milgram, 2008). Boomers might recognise that they need to continue learning and developing themselves but are not as focused on formal education or development as their younger counterparts, preferring training courses and on-the-job training (Orciani, 2009). Table 7 presents a summary of the total reward package preference of each generation.

Respondents were asked to select the four most probable rewards they would select, should these rewards be offered by another company, as depicted in Table 8 .

Table 8 shows that the monetary components of reward strongly impact all decisions made, regardless of generation. There were more differences in other categories; for instance,

TABLE 5: Preferences in rewards amongst respondants.

\begin{tabular}{|c|c|c|}
\hline Reward type & $\begin{array}{l}\text { Difference in medians (Kruskal-Wallis analysis } \\
\text { of variance) }\end{array}$ & Difference between groups (Bonferroni test) \\
\hline Salary & $p<0.01$ & Boomers and Generation $X$ differ from Generation $Y$ \\
\hline Company share scheme & $p<0.01$ & Boomers and Generation $\mathrm{X}$ differ from Generation $\mathrm{Y}$ \\
\hline Annual leave commutation & $p<0.01$ & Boomers and Generation $\mathrm{X}$ differ from Generation $\mathrm{Y}$ \\
\hline Pleasant work environment & $p<0.01$ & Boomers and Generation $\mathrm{Y}$ differ from Generation $\mathrm{X}$ \\
\hline Company BEE share scheme & $p<0.01$ & Boomers differ from Generation $X$ and Generation $Y$ \\
\hline Bonuses & $p=0.023$ & Generation $X$ differs from Generation $Y$ \\
\hline Cash incentives & $p=0.010$ & Boomers differ from Generation $Y$ \\
\hline Outcome-based remuneration or commission & $p=0.023$ & All groups differ \\
\hline Long service awards & $p<0.01$ & All groups differ \\
\hline Non-financial recognition awards & $p<0.01$ & All groups differ \\
\hline Time off work in recognition of hard work and secondment & $p<0.01$ & All groups differ \\
\hline Study bursary - Partially paid & $p<0.01$ & All groups differ \\
\hline Study bursary - Fully paid & $p<0.01$ & All groups differ \\
\hline Structured development programme & $p<0.01$ & All groups differ \\
\hline Training courses & $p<0.01$ & All groups differ \\
\hline On-the-job training & $p<0.01$ & All groups differ \\
\hline External conferences & $p<0.01$ & All groups differ \\
\hline Flexible working hours & $p<0.01$ & All groups differ \\
\hline Gym facilities & $p<0.01$ & All groups differ \\
\hline Wellness programme & $p<0.01$ & All groups differ \\
\hline
\end{tabular}


Generation $X$ had a strong preference towards 'flexible working hours' (Nordenfelt, 1993).

Interestingly, Boomers also rated complete study bursaries as a preference when changing employers, along with the younger generations.

\section{Research question 2: Does a total reward strategy address the preferences of each of the individual generations?}

Table 9 summarises the reward preferences for each group.

\section{Research question 3: Do generation-specific rewards improve the company's ability to attract, motivate and retain their employees?}

Participants were asked to compare what they received to others' rewards for similar responsibilities in different companies. Table 10 illustrates the different generations' perceptions of difference.

It is evident from Table 10 that a difference between the generations' perceptions of what they receive as benefits was evident in almost all categories. Generation $Y$ generally stood out as different from the other groups in their perceptions.

TABLE 6: Preferences in rewards amongst respondents.

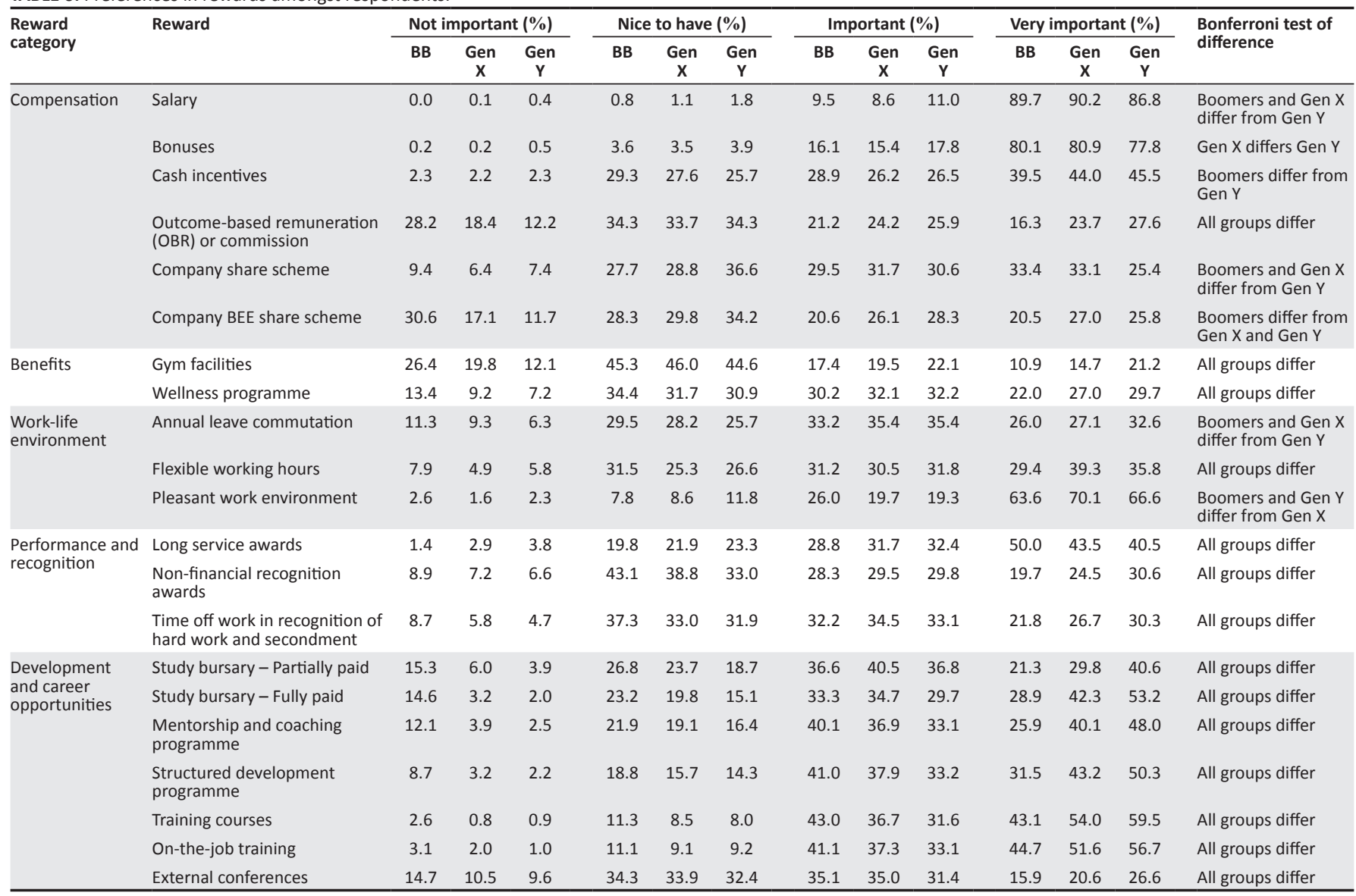

TABLE 7: The preferences of the generations towards the components of the total reward package in the company.

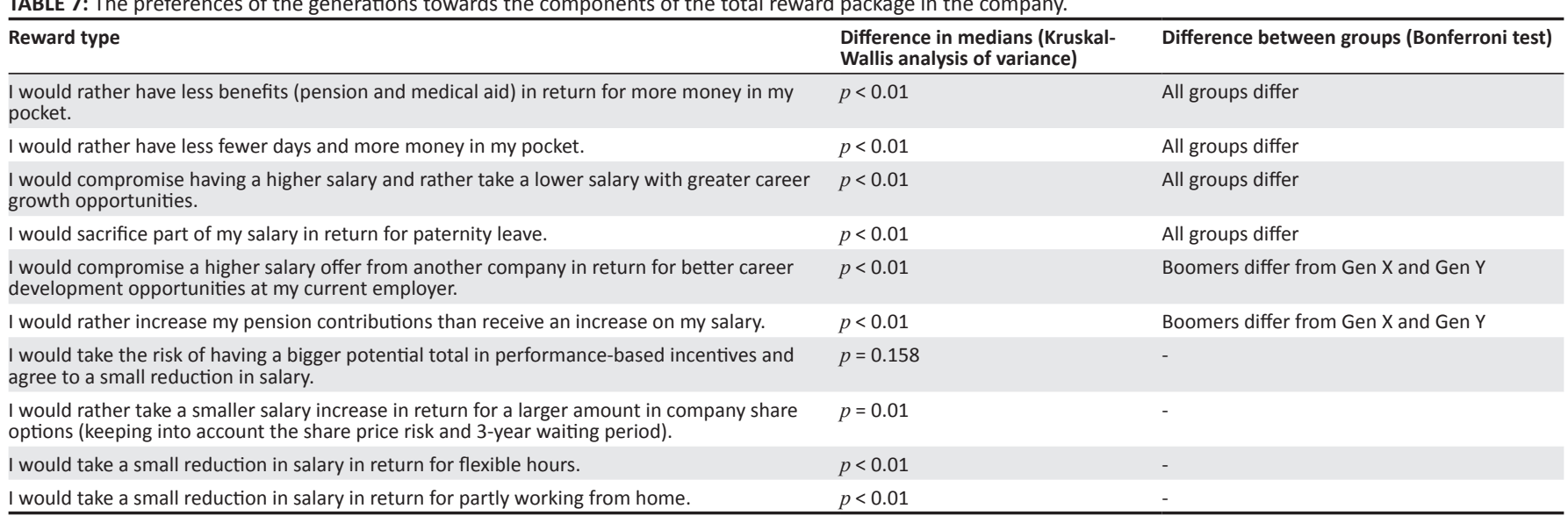

BB, baby boomers; Gen X, Generation X; Gen Y, Generation Y. 
TABLE 8: Preferences in benefits if they were offered by another company.

\begin{tabular}{|c|c|c|c|c|c|c|c|c|c|c|c|c|c|c|}
\hline \multirow{2}{*}{$\begin{array}{l}\text { Reward } \\
\text { category }\end{array}$} & \multirow[t]{2}{*}{ Reward } & \multicolumn{3}{|c|}{ Most important (\%) } & \multicolumn{3}{|c|}{ Second most important (\%) } & \multicolumn{3}{|c|}{ Third most important (\%) } & \multicolumn{3}{|c|}{ Fourth most important (\%) } & \multirow{2}{*}{$\begin{array}{l}\text { Bonferroni } \\
\text { test of } \\
\text { difference }\end{array}$} \\
\hline & & BB & Gen X & Gen Y & BB & Gen X & Gen $Y$ & BB & Gen X & Gen Y & BB & Gen X & Gen Y & \\
\hline \multirow[t]{2}{*}{ Compensation } & Salary & 44.8 & 42.3 & 41.5 & 26.0 & 27.0 & 23.7 & 16.8 & 17.4 & 18.7 & 14.3 & 17.7 & 18.2 & Not applicable \\
\hline & Shares & 18.7 & 16.9 & 14.0 & 26.6 & 27.2 & 23.1 & 30.7 & 28.1 & 31.7 & 36.3 & 39.3 & 35.4 & $\begin{array}{l}\text { Boomers differ } \\
\text { from Gen Y }\end{array}$ \\
\hline \multirow[t]{2}{*}{ Benefits } & $\begin{array}{l}\text { Better } \\
\text { medical and } \\
\text { pension } \\
\text { benifits }\end{array}$ & 21.9 & 17.6 & 17.9 & 38.3 & 34.9 & 38.8 & 25.5 & 29.8 & 30.1 & 14.3 & 17.7 & 18.2 & $\begin{array}{l}\text { Boomers differ } \\
\text { from Gen X } \\
\text { and Gen Y }\end{array}$ \\
\hline & $\begin{array}{l}\text { More leave } \\
\text { days }\end{array}$ & 12.4 & 10.3 & 14.4 & 20.5 & 20.4 & 20.3 & 31.0 & 30.0 & 29.9 & 36.3 & 39.3 & 35.4 & Not applicable \\
\hline \multirow[t]{2}{*}{$\begin{array}{l}\text { Work-life } \\
\text { environment }\end{array}$} & $\begin{array}{l}\text { Flexible } \\
\text { working hours }\end{array}$ & 26.9 & 32.0 & 31.4 & 17.2 & 21.0 & 18.8 & 20.2 & 20.5 & 20.8 & 35.7 & 26.5 & 29.0 & $\begin{array}{l}\text { Boomers and } \\
\text { Gen X differ } \\
\text { from Gen } Y\end{array}$ \\
\hline & $\begin{array}{l}\text { Better } \\
\text { company } \\
\text { culture and } \\
\text { working } \\
\text { environment }\end{array}$ & 14.1 & 16.5 & 16.5 & 22.5 & 22.1 & 26.2 & 31.5 & 29.3 & 28.3 & 31.9 & 32.1 & 29.0 & $\begin{array}{l}\text { All groups } \\
\text { differ }\end{array}$ \\
\hline $\begin{array}{l}\text { Performance and } \\
\text { recognition }\end{array}$ & $\begin{array}{l}\text { Better } \\
\text { recognition } \\
\text { and } \\
\text { celebration }\end{array}$ & 18.1 & 16.7 & 16.4 & 24.2 & 21.2 & 23.0 & 28.0 & 27.7 & 29.3 & 29.7 & 34.4 & 31.3 & $\begin{array}{l}\text { All groups } \\
\text { differ }\end{array}$ \\
\hline \multirow[t]{2}{*}{$\begin{array}{l}\text { Development } \\
\text { and career } \\
\text { opportunities }\end{array}$} & $\begin{array}{l}\text { Training, } \\
\text { career } \\
\text { development } \\
\text { and growth }\end{array}$ & 16.6 & 21.9 & 26.6 & 23.5 & 25.6 & 27.6 & 34.1 & 32.2 & 26.3 & 25.8 & 20.3 & 19.5 & $\begin{array}{l}\text { All groups } \\
\text { differ }\end{array}$ \\
\hline & $\begin{array}{l}100 \% \text { study } \\
\text { bursary }\end{array}$ & 23.4 & 23.5 & 24.3 & 12.8 & 21.1 & 22.7 & 27.5 & 19.6 & 21.0 & 36.3 & 35.8 & 32.0 & $\begin{array}{l}\text { All groups } \\
\text { differ }\end{array}$ \\
\hline
\end{tabular}

BB, baby boomers; Gen X, Generation X; Gen Y, Generation Y.

TABLE 9: Preferred reward for the different generations in the company.

\begin{tabular}{ll}
\hline Generation & Preferred reward \\
\hline Baby Boomers & Fixed and long-term compensation rather than variable compensation \\
& Long service recognition \\
& Development and career opportunities in the form of informal training \\
Meneration X & More of a balance between fixed and variable compensation \\
& Balanced work-life environment especially flexible working hours \\
Development and career opportunities with no inclination to a specific type of training & A balanced view on compensation, but leaning more towards variable pay rather than fixed \\
Generation Y & Non-financial recognition is very important \\
& Development and career opportunities were the highest of all generations in all the different types of training listed \\
\hline
\end{tabular}

TABLE 10: Comparison between employers of reward package received.

\begin{tabular}{lll}
\hline Reward type & Difference in medians (Kruskal-Wallis analysis of variance) & Difference between groups (Bonferroni test) \\
\hline Salary & $p<0.01$ & Boomers and Generation $\mathrm{X}$ differ from Generation $\mathrm{Y}$ \\
Bonuses & $p<0.01$ & Boomers and Generation $\mathrm{X}$ differ from Generation $\mathrm{Y}$ \\
Leave & $p<0.01$ & Boomers and Generation $\mathrm{X}$ differ from Generation $\mathrm{Y}$ \\
$\begin{array}{l}\text { Pension fund } \\
\text { Medical aid }\end{array}$ & $p<0.01$ & Boomers and Generation $\mathrm{X}$ differ to Generation $\mathrm{Y}$ \\
$\begin{array}{l}\text { Pleasant physical work } \\
\text { environment }\end{array}$ & $p<0.01$ & All groups differ \\
$\begin{array}{l}\text { Wellness benefits } \\
\text { Training and development }\end{array}$ & $p=0.01$ & Boomers and Generation $\mathrm{X}$ differ from Generation $\mathrm{Y}$ \\
Flexible working hours & $p<0.01$ & - \\
\hline
\end{tabular}

TABLE 11: Employee satisfaction with reward package received.

\begin{tabular}{lll}
\hline Reward type & Difference in medians (Kruskal-Wallis analysis of variance) & Difference between groups (Bonferroni test) \\
\hline Salary & $p<0.01$ & Boomers and Generation $\mathrm{X}$ differ from Generation $\mathrm{Y}$ \\
Bonuses & $p<0.01$ & Boomers and Generation $\mathrm{X}$ differ from Generation $\mathrm{Y}$ \\
Leave & $p<0.01$ & Boomers and Generation $\mathrm{X}$ differ from Generation $\mathrm{Y}$ \\
$\begin{array}{l}\text { Pension fund } \\
\text { Pleasant physical work }\end{array}$ & $p<0.01$ & Boomers and Generation $\mathrm{X}$ differ from Generation $\mathrm{Y}$ \\
environment & $p<0.01$ & Boomers and Generation X differ from Generation $\mathrm{Y}$ \\
Flexible working hours & $p<0.01$ & Boomers differ from Generation $\mathrm{Y}$ \\
Medical aid & $p<0.01$ & All groups differ \\
Wellness benefits & $p=0.048$ & - \\
\hline Training and development & $p=0.358$ & - \\
\hline
\end{tabular}


Table 11 illustrates how the levels of satisfaction with different reward types also differed.

In order to further probe this finding, participants were asked to rate their employer's rewards in comparison to other companies. The results are presented in Table 12.

The majority of employees were satisfied with their rewards. In relation to the other generations, Generation $\mathrm{Y}$ was the least satisfied. Again, benefits were well rated, except for 'medical aid', by Generation Y.

When asked to choose the four benefits with the most appeal and attraction from another workplace, there were no clear pull factors. Generation X does appear to favour the work-life environment, whilst Generation Y rates career development and opportunities highly.

\section{Discussion}

\section{Research question 1: Does a generation-based preference for reward exist?}

The research supports Bussin and Fletcher's (2008) study, which found a generational reward preference in South Africa. Specifically, the research found that Boomers preferred reward strategies such as fixed and long-term compensation, long service recognition and career development and training in the form of informal training. Generation Xers preferred a balance between fixed and variable income and more work-life balance (especially flexible hours). Generation Ys also preferred a balance between fixed and variable compensation but did show some indication that they would be comfortable with more variable pay. For Generation Y, non-financial recognition was regarded as highly important, as was training and career development (using all types of training methods).
These findings show a distinction between the generations' preference for reward, especially in terms of the type of monetary reward provided and the 'quality of work life' rewards. These reward types all exist in various total reward strategies and can be used to incentivise and motivate staff according to their preference. Customisation of the reward model, based on generational preferences, would also better cater for the life stage and associated work stage of individuals; for example, Generation Y employees are less likely to be interested in long service awards, as their age precludes them from benefiting from these for some time.

Past research has provided evidence for specific work and reward preferences amongst different generational cohorts. The most common means of describing these cohorts tends to be through the use of the terms Generation Y, Generation $X$, Baby Boomers and veterans. Generational theory attaches meaning to the terminology used, based on defining events in the collective lives of each cohort. The inherent problem is that these categories, and associated life events, are Western concepts. In South Africa, the use of the generational cohorts appears to be valuable as they indicate a specific model of age segmentation and similar trends in work preference have been found. For instance, Masibigiri and Nienaber (2011) found that the retention of South African Generation Xers depended on issues such as work-life balance and flexible rewards. However, this does not suggest that level of compensation is not important, as the participants in the Masibigiri and Nienaber study felt that the amount of compensation reflected their value as an asset for the organisation.

\section{Research question 2: Does a total reward strategy address the preferences of each of the individual generations?}

The company sampled in this study used many of the existing components of the WorldatWork total rewards model

TABLE 12: The satisfaction levels of employees with regard to rewards received.

\begin{tabular}{|c|c|c|c|c|c|c|c|c|c|c|c|c|c|c|c|c|c|}
\hline \multirow{3}{*}{$\begin{array}{l}\text { Reward } \\
\text { category }\end{array}$} & \multirow{3}{*}{$\begin{array}{l}\text { Reward } \\
\text { Salary }\end{array}$} & \multicolumn{3}{|c|}{ Irrelevant to me (\%) } & \multicolumn{3}{|c|}{ Very dissatisfied (\%) } & \multicolumn{3}{|c|}{ Dissatisfied (\%) } & \multicolumn{3}{|c|}{ Satisfied (\%) } & \multicolumn{3}{|c|}{ Very satisfied(\%) } & \multirow{2}{*}{$\begin{array}{l}\text { Bonferroni } \\
\text { test of } \\
\text { difference }\end{array}$} \\
\hline & & \multirow{2}{*}{$\begin{array}{l}\text { BB } \\
0.4\end{array}$} & \multicolumn{2}{|c|}{ Gen X Gen Y } & \multirow{2}{*}{$\begin{array}{l}\text { BB } \\
7.0\end{array}$} & \multicolumn{2}{|c|}{ Gen X Gen Y } & \multirow{2}{*}{$\frac{\text { BB }}{26.1}$} & \multicolumn{2}{|c|}{ Gen $X$ Gen $Y$} & \multirow{2}{*}{$\frac{\text { BB }}{61.4}$} & \multicolumn{2}{|c|}{ Gen $X$ Gen $Y$} & \multirow{2}{*}{$\begin{array}{l}\text { BB } \\
5.1\end{array}$} & \multicolumn{2}{|c|}{ Gen $X$ Gen $Y$} & \\
\hline & & & 0.8 & 1.5 & & 13.2 & 18.3 & & 28.1 & 33.2 & & 52.3 & 42.2 & & 5.6 & 4.8 & $\begin{array}{l}\text { All groups } \\
\text { differ }\end{array}$ \\
\hline \multirow[t]{7}{*}{ Benefits } & $\begin{array}{l}\text { Employee } \\
\text { banking }\end{array}$ & 3.2 & 4.0 & 4.5 & 4.7 & 9.8 & 11.6 & 25.8 & 29.6 & 29.5 & 61.9 & 51.4 & 48.9 & 4.4 & 5.2 & 5.5 & $\begin{array}{l}\text { Boomers } \\
\text { differ from } \\
\text { Gen } X \text { and } \\
\text { Gen } Y\end{array}$ \\
\hline & $\begin{array}{l}\text { Your number of } \\
\text { days for family } \\
\text { responsibility } \\
\text { leave }\end{array}$ & 4.7 & 2.6 & 4.8 & 2.8 & 6.9 & 10.1 & 11.6 & 19.3 & 22.9 & 72.0 & 63.4 & 54.6 & 8.9 & 7.8 & 7.7 & $\begin{array}{l}\text { All groups } \\
\text { differ }\end{array}$ \\
\hline & $\begin{array}{l}\text { Your number of } \\
\text { study leave days }\end{array}$ & 29.0 & 14.4 & 12.6 & 1.8 & 4.6 & 8.4 & 6.2 & 12.3 & 17.0 & 56.5 & 61.8 & 53.2 & 6.5 & 6.9 & 8.8 & $\begin{array}{l}\text { Boomers } \\
\text { differ from } \\
\text { Gen } X \text { and } \\
\text { Gen } Y\end{array}$ \\
\hline & $\begin{array}{l}\text { Your number of } \\
\text { annual leave days }\end{array}$ & 0.3 & 0.7 & 1.3 & 1.6 & 3.0 & 6.4 & 7.5 & 10.3 & 15.5 & 76.6 & 72.8 & 63.3 & 14.0 & 13.2 & 13.5 & $\begin{array}{l}\text { All groups } \\
\text { differ }\end{array}$ \\
\hline & $\begin{array}{l}\text { Your number of } \\
\text { sick leave days }\end{array}$ & 5.0 & 3.4 & 2.9 & 0.5 & 1.3 & 2.6 & 3.1 & 3.3 & 5.7 & 78.0 & 77.9 & 71.0 & 13.4 & 14.1 & 17.8 & - \\
\hline & $\begin{array}{l}\text { The maternity } \\
\text { leave policy }\end{array}$ & 60.4 & 35.5 & 31.8 & 0.3 & 4.0 & 5.2 & 1.6 & 6.4 & 8.1 & 31.9 & 46.1 & 45.0 & 5.8 & 8.0 & 9.9 & $\begin{array}{l}\text { Boomers } \\
\text { differ from } \\
\text { Gen } X \text { and } \\
\text { Gen } Y\end{array}$ \\
\hline & Your medical aid & 17.9 & 16.9 & 8.8 & 9.4 & 17.6 & 33.6 & 15.2 & 21.4 & 24.5 & 48.8 & 39.0 & 28.9 & 8.7 & 5.1 & 4.2 & $\begin{array}{l}\text { All groups } \\
\text { differ }\end{array}$ \\
\hline Work-life environment & $\begin{array}{l}\text { Your physical } \\
\text { working } \\
\text { environment }\end{array}$ & 1.1 & 0.7 & 1.5 & 4.7 & 6.3 & 6.5 & 15.0 & 13.2 & 12.5 & 61.5 & 62.2 & 59.1 & 17.7 & 17.6 & 20.4 & - \\
\hline
\end{tabular}

BB, baby boomers; Gen X, Generation X; Gen Y, Generation Y. 
with their employees. It was clear that each generation, on aggregate, received the rewards they preferred. In this instance, the rewards offered did meet their needs, but it was also clear that there were different requirements amongst the age groups. This supports the findings of other South African research, such as that of Masibigiri and Nienaber (2011), but may be specific to this sample, as other research has indicated no differences amongst the generations (Bussin \& Moore, 2012). In addition, Giancola (2006) has argued that the generation gap between age cohorts is not a sensitive measure of difference. His research does indicate that reward preferences may be linked to specific cohorts, such as retirement planning for Boomers and career development for Generation Y. His argument is that this relates to the period in the person's career, rather than to their age cohort per se.

\section{Research question 3: Do generation-specific rewards improve the company's ability to attract, motivate and retain their employees?}

Overall, the generations felt that their company offered rewards that were sufficient and of market value. This demonstrates satisfaction with the rewards offered, but it does not indicate whether the rewards were generation specific or merely fulfilled the needs of the generations. Further predictive research into whether the reward offer was an important component in the retention and attraction of staff is required.

It should also be noted that this study was conducted during the recovery period following the $2007 / 2008$ recession and economic slowdown. Employees may have been more aware and focused on monetary rewards than non-monetary rewards during this time.

\section{Practical and theoretical implications}

The current research has contributed to the international literature on generational theory by extending findings on generational differences in reward preferences to a South African context. Further investigation into each age cohort would add knowledge on the specific drivers and values of each one. This is especially important as research in this area in South Africa does not indicate consistent findings (see Bussin \& Moore, 2012, for instance).

Non-monetary rewards are becoming increasingly important in total rewards models; this is evidenced in the positive way in which the younger generations value them.

TABLE 13: Preferences in reward if offered by another company.

\begin{tabular}{ll}
\hline Reward & Result \\
\hline Compensation & High preference by all generations \\
$\begin{array}{l}\text { Benefits } \\
\text { Work-life environment }\end{array}$ & $\begin{array}{l}\text { High preference by all generations } \\
\begin{array}{l}\text { Performance and } \\
\text { recognition }\end{array}\end{array}$ \\
$\begin{array}{l}\text { Career development and } \\
\text { opportunities }\end{array}$ & $\begin{array}{l}\text { High preference by all generations } \\
\text { the highest preference of all }\end{array}$ \\
\hline
\end{tabular}

Organisations could benefit practically from this research by using generational preferences to tailor reward packages for candidates. Performance discussions with existing staff offer an opportunity to guide reward strategies to suit their needs. The results from the study can be used to guide the employer's strategy in their methods of engaging or retaining their key employees.

\section{Limitations of the study}

The following limitations need to be considered for this study:

- Due to time constraints or any other potential reasons for decline, not all employees of the selected financial institution chose to participate in the research and thus the results may not be representative of the population.

- The categorisation of generational cohorts used an international definition, which may not be completely applicable to the South African context.

- The study only includes the workforce of one company found in the financial services industry. This limits the applicability to other financial institutions and organisations in South Africa more broadly.

- The age categories did not have the same number of people in them, making the use of parametric statistics impossible.

- The exclusion of the veteran (traditionalist) generation due to non-response to the survey caused the data analysis and conclusions drawn to be done without their input.

\section{Conclusion}

Considering future demographic trends, employees from Generation $X$ and Generation $Y$ will start to dominate the composition of the workforce. Employers need to consider the preferences and motivations of these generations in order to attract and retain talent, as well as to increase productivity. Reward strategy plays a key role in defining the employee value proposition and, as such, demands the continued attention of employers. One-size-fits-all reward strategies do not take individual preferences into account, but it can be argued that large employers do not have the capacity to customise reward packages at an individual level. The complexity of this type of customisation would lead to significant expense in terms of time and coordination. It is thus beneficial for organisations to find a way to segment the workforce according to reward preference, in a way that provides a balance between individual customisation and organisational efficiency.

This research investigated the role of generational theory as a means of segmenting the workforce to understand reward preference. The findings show that there are indeed preferences in reward based on defined generational cohorts (Boomers, Generation X and Generation Y). It is suggested that these preferences can be used to enhance the attraction and retention of employees. The use of a total rewards model is advocated in which a mix of financial and non-financial rewards is offered to employees in a manner that is consistent with preferences aligned to age and generation. 


\section{Acknowledgements}

\section{Competing interests}

The authors declare that they have no financial or personal relationship(s) that may have inappropriately influenced them in writing this article.

\section{Authors' contributions}

M.B. (University of Johannesburg) was the principle investigator and was responsible for the design and execution of the project and writing the article. D.J.v.R. (University of Pretoria) was responsible for fieldwork and writing up the research.

\section{References}

Armstrong, M., \& Murlis, H. (2007). Reward management: A handbook of remuneration strategy and practice. London, England: Kogan Page.

BankSETA. (2010). Sector skills plan. Retrieved July 20, 2014, from http://www. bankseta.org.za/skills/..\%5Cdownloads\%5Cskills\%5CBANKSETA ssp update_2009_10.pdf

Bersin, J. (2008). The business impact of talent management. Banking Strategies, $84(5), 6$.

Boyd, B.K., \& Salamin, A. (2001). Strategic reward systems: A contingency model of pay system design. Strategic Management Journal, 22, 777-792. http://dx.doi. org $/ 10.1002 / \mathrm{smj} .170$

Bussin, M., \& Fletcher, S. (2008). Managing the generation mix. Retrieved July 20, 2014, from http://www.21century.co.za/index.php?option=com_contentandvie $w=$ articleandid=64: exploring-the-link-between-incentives-and-motivationandcat $\mathrm{d}=61$ :articlesandltemid $=55$

Bussin, M. \& Moore, A. (2012). Reward preferences for generations in selected information and communication technology companies. SA Journal of Human Resource Management, 10(1), Art. \#325, 9 pages.

Chan, D.S. (2005). Relationship between generation-responsive leadership behaviors and job satisfaction of generations $X$ and $Y$ professionals. Unpublished PhD and job satisfaction of generations $X$ and $Y$ professionals. Unpublished
dissertation, School of Advanced Studies, University of Phoenix, Phoenix, AZ.

Codrington, G. (2008, 10 May). Generation comparisons? @tomorrowtoday. Available from http://www.tmtd.biz/2008/05/10/generation-comparisons/\#more-1562

Codrington, G., \& Grant-Marshall, S. (2004). Mind the gap!, Rosebank, South Africa: Penguin Books.

Colon, E. (2005). The relation between generational differences and conflict management styles in a telemarketing call centre. Unpublished PhD dissertation, School of Advanced Studies, University of Phoenix, Phoenix, AZ.

Cummings, T.G., \& Worley, G.G. (2001). Essentials of organisational development and change. Cincinnati, $\mathrm{OH}$ : South-Western College Publishing.

Deal, J.J., Stawiski, S., Graves, L., Gentry, W., \& Ruderman, M. (2013), Motivation at work: Which matters more, generation or managerial level? Consulting Psychology Journal: Practice and Research, 65(1), 1-16. http://dx.doi.org/10.1037/a0032693

DeVills, R.D. (2003). Scale development: Theory and applications. (2nd edn.). California: Sage.

E-research. (2002). Analysis: A guide to total reward, Part 1., E-reward.co.uk Limited, London.

Ellis, M. (2009). Win the race for talent. Retrieved June 30, 2014, from http://www. sbnonline.com/Classes

Gentry, T. (2007). Re-engineering recognition. Workspan, 02/07, 47-48.

Giancola, F. (2006). The generation gap: More myth than reality. HR. Human Resource Planning, 29(4), 32-37.
Glass, A. (2007). Understanding generational differences for competitive success. Industrial and Commercial Training, 39, 98-103. http://dx.doi. org/10.1108/00197850710732424

Hatfield, S.L. (2002). Understanding the four generations to enhance workplace management. Association for Financial Professionals (AFP) Exchange, 22, 72-75.

Hayes, S. (1999). Is your company's rewards package out of sync?, Workforce, December, 115-116.

Horwitz, F.M., Bowmaker-Falconer, A., \& Searll, P. (1996). Human resource development and managing diversity in South Africa. International Journal of Manpower, 17, 134-151. http://dx.doi.org/10.1108/01437729610127604

Irvine, D. (2010). How to reward a multigenerational and culturally diverse workforce. Workspan: The Magazine of WorldatWork, 4, 63-68.

Kane, S. (2013). Generation Y. Retrieved July 19, 2014, from http://legalcareers.about. com/od/practicetips/a/GenerationY.htm

Khon, A. (2002). Rethinking rewards. In Harvard Business Review, On compensation, (pp. 51-76). Watertown, MA: Harvard Business School Publishing Corporation.

Kupperschmidt, B.R. (2000). Multigeneration employees: Strategies for effective management. The Health Care Manager, 19, 65-76. http://dx.doi. org/10.1097/00126450-200019010-00011

Lancaster, L.C., \& Stillman, D. (2002). When generations collide. New York, NY HarperCollins.

Landelahni. (2010). Financial services survey. Retrieved July 20, 2014, from http:// www.hrfuture.net/news/professional-skills-needed-to-fuel-financial-servicessector-renewal.php? Itemid=812

Linne, L. (2009). Obtaining and retaining the best talent. Rough Notes, 152(6), 32-34.

Lyons, S. (2003). An exploration of generational values in life and at work. Unpublished PhD dissertation, Faculty of Graduate Studies, Carleton University, Ottawa, Canada.

Masibigiri, V., \& Nienaber, H. (2011). Factors affecting the retention of Generation X public servants: An exploratory study. SA Journal of Human Resource Management 9(1), Art. \#318, 11 pages. http://dx.doi.org/10.4102/sajhrm.v9i1.318

Milgram, R. (2008). Attracting and retaining a multi-generational workforce. The Magazine of WorldatWork, 6, 1-14.

Mohlala, J.G. (2011). Employee retention within Standard Bank Group IT. MBA thesis, Department of Industrial Psychology and People Management, University of Johannesburg, Johannesburg, South Africa.

Moore, A. (2009). Reward preferences for generations in selected ICT companies. Unpublished master's thesis, Department of Industrial Psychology and People Management, University of Johannesburg, Johannesburg, South Africa.

Nienaber, R., Bussin, M., \& Henn, C. (2011). The relationship between personality types and reward preferences. Acta Commercii, 11(2), Art. \#153, 9 pages.

Nordenfelt, L. (1993). Quality of life, health and happiness. Avebury, England:Aldershot.

Orciani, D. (2009). A manager's perspective on how to effectively manage the multigenerational workforce. The Magazine of WorldatWork, 7, 79-80.

Pallant, J. (2007). SPSS survival manual: A step-by-step guide to data analysis using SPSS for Windows. (3rd edn). McGraw Hill - Open University Press.

Scott, D., \& McMullen, T. (2010). The impact of rewards programs on employee engagement. WorldatWork. Retrieved July 20, 2014, from http://www. worldatwork.org/waw/adimLink?id=39032

Shaul, C. (2007). The attitude toward money as a reward system between the age groups corresponding to the boomers, generation $X$, and generation $Y$ employees. Unpublished PhD dissertation, Marshall Goldsmith School of Management, Alliant International University, San Diego, CA.

Smola, W.K., \& Sutton, C.D. (2002). Generational differences: revisiting generational work values for the new millennium. Journal of Organisational Behaviour, 23 363-382. http://dx.doi.org/10.1002/job.147

WorldatWork. (2006). WorldatWork total rewards model. Retrieved November 15,2013 , from http://www.worldatwork.org/waw/aboutus/html/aboutus-
whatis.html

WorldatWork. (2008). WorldatWork total rewards model: A framework for strategies to attract, motivate and retain employees. Retrieved November 15, 2014, from to attract, motivate and retain employees. Retrieved November 15, 2014

Zemke, R. Raines, C., \& Filipczack, B. (2000). Generations at work: Managing the clash of the veterans, boomers, Xers and nexters in your workplace. New York, NY: AMACOM. 